\title{
Penerapan Tekhnik Konflik Kognitif dalam Pembelajaran Conceptual Change Berbantuan Peta Konsep untuk Meningkatkan Hasil Belajar Fisika pada Siswa Kelas $\mathrm{X}_{\mathrm{A}}$ SMA Al-Khairaat Kalukubula
}

\author{
Nurul Fitriana, Darsikin, Marungkil Pasaribu \\ Email : Nurul_fitriana46@yahoo.co.id \\ Prodi Studi Pendidikan Fisika, Jurusan Pendidikan MIPA, Universitas Tadulako \\ JI. Soekarno Hatta KM. 9 Kampus Bumi Tadulako Tondo - Sulawesi Tengah
}

\begin{abstract}
Abstrak - Penelitian ini merupakan penelitian tindakan kelas yang bertujuan untuk meningkatkan hasil belajar fisika pada siswa SMA Al-Khairaat Kalukubula dengan menerapkan tekhnik konflik kognitif dalam pembelajaran conceptual change berbantuan peta konsep di kelas XA. Desain penelitian mengikuti model Kemmis dan Mc. Taggart dengan subyek penelitian yang melibatkan 26 orang siswa. Materi yang diajarkan pada siklus I untuk pertemuan pertama adalah Besaran-besaran Fisika Pada Gerak Lurus dan pertemuan kedua adalah Gerak Lurus Beraturan (GLB), materi pada siklus II adalah Gerak Lurus Berubah Beraturan (GLBB). Data yang dikumpulkan adalah data kuantitatif dan kualitatif. Hasil penelitian pada siklus I didapatkan ketuntasan klasikal sebesar $80.77 \%$ dan daya serap klasikal $80.00 \%$, aktivitas guru berada pada kategori baik dengan rata-rata $82.29 \%$ dan aktivitas siswa berada pada kategori baik dengan rata-rata $81.82 \%$. Pada siklus II ketuntasan belajar klasikal sebesar $92.31 \%$ dan daya serap klasikal sebesar $80.26 \%$, aktivitas guru berada pada kategori sangat baik dengan rata-rata $95.83 \%$ dan aktivitas siswa berada pada kategori sangat baik dengan rata-rata 93.18\%. Berdasarkan indikator kinerja, peningkatan hasil belajar siswa yaitu jika daya serap individu memperoleh nilai minimal $68 \%$ dari skor ideal dan ketuntasan klasikal minimal $80 \%$. Sehingga dapat disimpulkan bahwa penerapan tekhnik konflik kognitif dalam pembelajaran conceptual change berbantuan peta konsep dapat meningkatkan hasil belajar fisika pada siswa kelas XA SMA Al-Khairaat Kalukubula.
\end{abstract}

Kata Kunci: Tekhnik Konflik Kognitif; Conceptual Change; Peta Konsep; Hasil Belajar Fisika; dan Gerak Lurus

\section{PENDAHULUAN}

Kurikulum KTSP berimplikasi pada proses pembelajaran yang menekankan pencapaian kompetensi. Guru harus melaksanakan proses pembelajaran dengan mengacu pada pencapaian kompetensi, di samping menekankan pada selesainya pokok bahasan yang diajarkan di kelas.

Seorang guru harus memiliki strategi agar siswa dapat belajar secara efektif dan efisien, sehingga nantinya akan mencapai tujuan seperti yang diharapkan. Salah satu langkah guru untuk memiliki strategi pembelajaran tersebut ialah harus menguasai tekhnik-tekhnik penyajian, atau biasanya disebut model mengajar. Inilah yang merupakan tujuan pembelajaran dalam KTSP yaitu bagaimana membelajarkan siswa untuk belajar [1].

Setiap siswa membutuhkan guru yang profesional dalam mengembangkan suatu pembelajaran untuk mencapai hasil belajar yang baik, pelaksanaan pembelajaran di sekolah merupakan salah satu tugas utama pada guru dan pembelajaran dapat diartikan sebagai kegiatan yang ditujukan pada siswa. Sehingga guru harus merancang model pembelajaran yang dapat mengaktifkan siswa di kelas.

Berdasarkan data dan informasi yang diperoleh dari guru mata pelajaran fisika kelas $X$ SMA Al-Khairaat Kalukubula, bahwa rendahnya hasil belajar siswa dalam mata pelajaran fisika dapat dibuktikan dari rendahnya nilai hasil evaluasi siswa, sebagaimana terlihat pada Tabel 1 .

Tabel 1 Data Nilai Rata-Rata Ujian Mata Pelajaran Fisika SMA Al-Khairaat Kalukubula Tahun Ajaran 2011/2012.

\begin{tabular}{|c|c|c|}
\hline \multirow{2}{*}{$\begin{array}{c}\text { Tahun } \\
\text { Ajaran/semester }\end{array}$} & \multicolumn{2}{|c|}{ Nilai Rata-rata Kelas } \\
\cline { 2 - 3 } & Kelas XA & Kelas XB \\
\hline 2011/2012 & 62.0 & 69.7 \\
Ganjil & 65.0 & 70.9 \\
Genap & \\
\hline \multicolumn{2}{|c|}{ Sumber : SMA Alkhairaat Kalukubula } \\
\hline
\end{tabular}




\section{Jurnal Pendidikan Fisika Tadulako (JPFT) \\ Vol. 1 No. 3}

ISSN 23383240

Hasil observasi awal yang dilaksanakan di SMA Al-Khairaat Kalukubula, didapatkan hal-hal yang dapat menghambat tercapainya hasil yang baik dari proses belajar-mengajar mata pelajaran fisika. Fisika dianggap mata pelajaran yang sulit oleh sebagian besar siswa, sehingga membuat mereka kurang berminat terhadap mata pelajaran tersebut. Hal ini terlihat pada rendahnya partisipasi siswa untuk aktif dalam proses pembelajaran fisika dan kurangnya pemahaman mereka terhadap konsep fisikanya. Hal lainya adalah konsep awal yang mereka bawa kadang-kadang tidak sesuai dengan konsep ilmiah (miskonsepsi).

Salah satu faktor penyebab rendahnya hasil belajar fisika pada siswa kelas XA SMA AlKhairaat Kalukubula adalah guru belum maksimal dalam mengajar, yang mengakibatkan pengetahuan siswa masih kurang sehingga hasil belajar yang dicapai oleh siswa belum memuaskan. Dan kemungkinan Siswa belum memahami konsep yang sebenarnya dan tidak dapat menyerap materi sebelumnya yang telah diajarkan oleh guru. Oleh karena itu, untuk memperbaiki proses pembelajaran yang menyebabkan miskonsepsi siswa, maka guru dapat menggunakan tekhnik konflik kognitif. Dengan teknik ini guru bisa mengerjakan apa yang telah diketahui dalam bentuk yang lebih sederhana dan dapat mengetahui sampai di mana tingkat pemahaman siswa terhadap konsep fisika yang diberikan.

Sesuai dengan uraian permasalahan tersebut, diterapkan suatu model pembelajaran yang dapat meningkatkan hasil belajar fisika pada siswa kelas XA yaitu tekhnik konflik kognitif dalam pembelajaran conceptual change berbantuan peta konsep. Peta konsep digunakan dalam kegiatan belajar mengajar hanya sebagai media yang disusun pada kertas kuarto dan diperlihatkan kepada siswa di depan kelas. Karena peta konsep merupakan media yang dapat membantu guru mengatur informasi yang akan diajarkan menjadi lebih ringkas sehingga memudahkan siswa untuk belajar dan salah satu alternatif yang sangat baik dalam pembelajaran.

1. Konflik Kognitif

Menurut Piaget dengan adanya Tekhnik Konflik Kognitif, guru bisa memberikan pertanyaan yang bersifat provokatif, yakni menghadapkan siswa pada persoalan yang bertentangan dan pendapat yang berbeda dengan pendapat - pendapat yang dimiliki oleh siswa sehingga nantinya guru akan mengetahui apakah siswa mengetahui konsep sebenarnya atau mengalami kesalahan konsep (konsepsi awal) [2].

2. Conceptual Change

Model conceptual change dikembangkan dari pandangan yang menyatakan bahwa dalam proses belajar (perolehan pengetahuan) selalu diawali dengan terjadinya konflik kognitif. Konflik kognitif dalam pembelajaran conceptual change tersebut yaitu konflik yang terbentuk saat terjadi interaksi antara pengetahuan awal yang dimiliki siswa dengan pengetahuan baru yang didapat dari hasil proses pembelajaran maupun interaksinya dengan lingkungan. Konflik kognitif tersebut hanya dapat diatasi melalui pengaturan diri (self regulation) oleh siswa yang sedang belajar. Dimana Self regulation yang dilakukan siswa yaitu dengan berusaha menyeimbangkan antara pengetahuan awal dengan pengetahuan baru, apabila tidak dapat dilakukan sendiri maka proses penyeimbangan tersebut dilakukan dengan bantuan guru melalui proses akomodasi dalam pembelajaran agar terjadi proses asimilasi [3].

\section{Peta Konsep}

Salah satu Penggunaan peta konsep dalam pembelajaran dapat memberikan manfaat pada guru yaitu Membuat guru untuk mengerjakan apa yang telah diketahui dalam bentuk yang lebih sederhana, merencanakan dan memulai suatu topik pembelajaran, serta mengolah kata kunci yang akan digunakan dalam pembelajaran. Sedangkan manfaat pada siswa yaitu Membantu untuk mengidentifikasi kunci konsep, menaksir atau memperkirakan hubungan pemahaman dan membantu dalam pembelajaran lebih lanjut [4]

Tekhnik Konflik Kognitif dalam pembelajaran conceptual Change dipilih karena Penelitian yang dilakukan oleh Dahlia (2008) menyatakan bahwa dengan menggunakan Teknik Konflik Kognitif dapat meningkatkan hasil belajar siswa Kelas VIII F SMP Negeri 3 Palu [5]. Dan penelitian yang dilakukan oleh Lisdawati (2008) menyatakan bahwa melalui pendekatan Konflik Kognitif dapat meningkatkan hasil belajar fisika pada siswa Kelas VIII SMP Negeri 2 Marawola [1].

Hipotesis tindakan pada penelitian ini adalah penerapan tekhnik konflik kognitif dalam model pembelajaran conceptual change berbantuan peta konsep dapat meningkatkan hasil belajar fisika pada siswa kelas XA SMA Alkhairaat Kalukubula. 


\section{METODOLOGI PENELITIAN}

Penelitian ini merupakan penelitian tindakan kelas (PTK) yang dilakukan dalam dua siklus. Masing-masing siklus melalui tahap perencanaan, pelaksanaan, observasi dan refleksi. Tahapan penelitian ini diadopsi dari alur PTK model Kurt Lewin yang dikembangkan oleh Mc. Taggart [6].

Subyek penelitian ini adalah seluruh siswa kelas XA SMA Al-Khairaat Kalukubula yang terdaftar pada semester ganjil tahun ajaran 2013/2014 yang berjumlah 26 orang siswa yang terdiri dari 17 orang siswa laki-laki dan 9 orang siswa perempuan, metode pengumpulan data pada penelitian ini, meliputi beberapa cara yaitu, observasi menggunakan lembar observasi dan tes hasil belajar. Faktor-faktor yang diteliti dalam penelitian ini adalah aktivitas guru, aktivitas siswa, afektif siswa, kinerja siswa, dan keterampilan sosial siswa serta hasil belajar siswa. Analisa data terbagi menjadi dua kelompok yaitu analisa data kuantitatif dan data kualitatif.

\section{HASIL DAN PEMBAHASAN}

Data hasil analisis penilaian observasi aktivitas guru siklus I dan siklus II dapat dilihat pada Tabel 2 .

Tabel 2 Hasil Observasi Aktivitas Guru Siklus I dan Siklus II

\begin{tabular}{|c|c|c|c|}
\hline Tabel 2 Hasil & Observasi Aktivitas Guru Siklus I dan Siklus II \\
\hline \multirow{2}{*}{ Siklus } & Pertemuan & $\begin{array}{c}\text { Rerata } \\
\text { Aktivitas } \\
\text { Guru (\%) }\end{array}$ & Kategori \\
\cline { 2 - 4 } & Pertama & 70.83 & Cukup \\
\hline Dua & Kedua & 93.75 & Sangat Baik \\
\hline
\end{tabular}

Dari Tabel 2 dapat diketahui bahwa persentase nilai rata-rata aktivitas guru siklus I pada pertemuan pertama berada pada kategori cukup sedangkan pada pertemuan kedua berada pada kategori sangat baik. Pada siklus II persentase nilai rata-rata aktivitas guru pada pertemuan pertama berada pada kategori sangat baik.

Data hasil analisis penilaian observasi aktivitas siswa siklus I dan siklus II dapat dilihat pada Tabel 3.

Tabel 3 Hasil Observasi Aktivitas Siswa Siklus I dan Siklus II
\begin{tabular}{|c|c|c|c|}
\hline Siklus & Pertemuan & $\begin{array}{c}\text { Rerata } \\
\text { Aktivitas } \\
\text { Siswa (\%) }\end{array}$ & Kategori \\
\hline \multirow{2}{*}{ Satu } & Pertama & 72.73 & Cukup \\
\cline { 2 - 4 } & Kedua & 90.91 & Baik \\
\hline Dua & Pertama & 93.18 & Sangat Baik \\
\hline
\end{tabular}

ISSN 23383240

Dari Tabel 3 dapat diketahui bahwa persentase nilai rata-rata aktivitas siswa siklus I pada pertemuan pertama berada pada kategori cukup sedangkan pada pertemuan kedua berada pada kategori baik. Pada siklus II persentase nilai rata-rata aktivitas siswa pada pertemuan pertama berada pada kategori sangat baik.

Data hasil analisis penilaian afektif siswa siklus I dan siklus II dapat dilihat pada Tabel 4.

Tabel 4 Hasil Analisis Penilaian Afektif Siswa Siklus I dan Siklus II
\begin{tabular}{|c|c|c|c|}
\hline Siklus & Pertemuan & $\begin{array}{c}\text { Rerata } \\
\text { Afektif } \\
\text { Siswa (\%) }\end{array}$ & Kategori \\
\hline \multirow{2}{*}{ Satu } & Pertama & 88.2 & Baik \\
\cline { 2 - 4 } & Kedua & 93.03 & Sangat Baik \\
\hline Dua & Pertama & 94.47 & Sangat Baik \\
\hline
\end{tabular}

Dari Tabel 4 dapat diketahui bahwa persentase nilai rata-rata keberhasilan afektif siswa siklus I pada pertemuan pertama berada pada kategori baik sedangkan pada pertemuan kedua berada pada kategori sangat baik. Pada siklus II persentase nilai rata-rata keberhasilan afektif siswa pada pertemuan pertama berada pada kategori sangat baik.

Data hasil analisis penilaian kinerja siswa siklus I dan siklus II dapat dilihat pada Tabel 5.

Tabel 5 Hasil Penilaian Kinerja Siswa Siklus I dan Siklus II
\begin{tabular}{|c|c|c|c|}
\hline \multirow{2}{*}{ Siklus } & Pertemuan & $\begin{array}{c}\text { Rerata } \\
\text { Kinerja Siswa } \\
(\%)\end{array}$ & Kategori \\
\hline \multirow{2}{*}{ Satu } & Pertama & 82.21 & Baik \\
\cline { 2 - 4 } & Kedua & 87.5 & Baik \\
\hline Dua & Pertama & 89.26 & Baik \\
\hline
\end{tabular}

Dari Tabel 5 dapat diketahui bahwa persentase nilai rata-rata keberhasilan kinerja siswa siklus I pada pertemuan pertama dan pertemuan kedua berada pada kategori baik. Pada siklus II persentase nilai rata-rata keberhasilan kinerja siswa pada pertemuan pertama berada pada kategori baik.

Data hasil analisis penilaian keterampilan sosial siswa siklus I dan siklus II dapat dilihat pada Tabel 6.

Tabel 6 Hasil Penilaian Keterampilan Sosial Siswa Siklus I dan Siklus II
\begin{tabular}{|c|c|c|c|} 
Siklus & Perata & $\begin{array}{c}\text { Rerampilan } \\
\text { Keterampian } \\
\text { Sosial Siswa } \\
(\%)\end{array}$ & Kategori \\
\hline \multirow{2}{*}{ Satu } & Pertama & 79.81 & Cukup \\
\cline { 2 - 4 } & Kedua & 87.26 & Baik \\
\hline Dua & Pertama & 91.35 & Sangat Baik \\
\hline
\end{tabular}


ISSN 23383240

Dari Tabel 6 dapat diketahui bahwa persentase nilai rata-rata keberhasilan keterampilan sosial siswa siklus I pada pertemuan pertama berada pada kategori cukup sedangkan pada pertemuan kedua berada pada kategori baik. Pada siklus II persentase nilai rata-rata keberhasilan keterampilan sosial siswa pada pertemuan pertama berada pada kategori sangat baik.

Data hasil belajar siswa siklus I dan siklus II dapat dilihat pada Tabel7.

Tabel 7 Hasil Belajar Siswa Siklus I dan Siklus II

\begin{tabular}{|c|l|c|c|}
\hline \multirow{2}{*}{ No } & \multirow{2}{*}{ Aspek Perolehan } & \multicolumn{2}{|c|}{ Hasil } \\
\cline { 3 - 4 } & Skor maksimal & 15 & Siklus II \\
\hline 2 & Skor Tertinggi & $14(8$ orang) & 14 (7 orang) \\
\hline 3 & Skor Terendah & 8 (2 orang) & 8 (1 orang) \\
\hline 4 & $\begin{array}{l}\text { Banyaknya siswa } \\
\text { yang belum tuntas }\end{array}$ & 5 orang & 2 orang \\
\hline 5 & $\begin{array}{l}\text { Banyaknya siswa } \\
\text { yang tuntas }\end{array}$ & 21 orang & 24 orang \\
\hline 6 & $\begin{array}{l}\text { Presentase } \\
\text { ketuntasan } \\
\text { klasikal }\end{array}$ & $80.77 \%$ & $92.31 \%$ \\
\hline 7 & $\begin{array}{l}\text { Presentase daya } \\
\text { serap klasikal }\end{array}$ & $80.00 \%$ & $80.26 \%$ \\
\hline 8 & Nilai rata-rata & $80.00 \%$ & $80.26 \%$ \\
\hline 9 & $\begin{array}{l}\text { Rata-rata daya } \\
\text { serap individu }\end{array}$ & $2080.00 \%$ & $2086.67 \%$ \\
\hline
\end{tabular}

Berdasarkan analisa tes hasil belajar yang dilakukan pada siklus I dan siklus II, diketahui bahwa hasil belajar fisika siswa kelas XA SMA Al-Khairaat Kalukubula sudah sangat baik, hanya ada 2 siswa yang tidak tuntas dari 26 siswa. Untuk Siklus I, persentase ketuntasan belajar klasikal (KBK) diperoleh $80.77 \%$ dan persentase daya serap klasikal (DSK) diperoleh $80.00 \%$. Sedangkan Untuk Siklus II, persentase ketuntasan belajar klasikal (KBK) diperoleh $92,31 \%$ dan persentase daya serap klasikal (DSK) diperoleh $80.26 \%$. Dari hasil presentase ketuntasan klasikal dan daya serap klasikal pada siklus I dan siklus II ini sudah mencapai standar ketuntasan klasikal dan daya serap klasikal yang telah ditetapkan yaitu $80 \%$. Hal ini disebabkan siswa dapat melaksanakan dengan baik kegiatan proses pembelajaran yang diberikan dengan mengunakan penerapan tekhnik konflik kognitif dalam pembelajaran conceptual change berbantuan peta konsep.

Dari hasil penelitian pada siklus I, terlihat masih terdapat beberapa kelemahannya. Diantaranya: (a) Siswa belum memahami materi yang diterimanya; (b) Siswa mengajukan jawaban tidak sesuai dengan jawaban yang sebenarnya (miskonsepsi siswa); (c) Ketika diskusi terjadi keributan dalam kelas; (d) Siswa yang berkemampuan tinggi belum bisa menghargai dan membimbing siswa yang berkemampuan rendah; (e) Peneliti secara keseluruhan pada siklus ini belum efektif menggunakan waktu.

Dilihat dari hasil observasi aktivitas guru pada siklus I untuk pertemuan pertama, diketahui bahwa tidak tuntasnya hasil belajar siswa ini disebabkan oleh beberapa faktor yaitu guru kurang maksimal dalam pembentukkan kelompok siswa; kurang memberikan kesempatan kepada siswa untuk merumuskan penjelasan; kurang mengarahkan siswa dalam membuat kesimpulan dan guru belum efektif menggunakan waktu. Sedangkan dari hasil observasi aktivitas siswa pada siklus I untuk pertemuan pertama, diketahui bahwa tidak tuntasnya hasil belajar siswa yaitu Siswa masih tetap mempertahankan konsep yang dimiliki (konsep awal); siswa kurang aktif dalam berkelompok; kurang menyimak penjelasan yang disampaikan oleh guru dan kurang menanggapi masalah yang diberikan oleh guru. Sebagaimana dapat dilihat dari hasil analisis aktivitas guru yang berada pada kategori baik dan aktivitas siswa yang masih berada pada kategori kurang dan cukup. Hal ini dapat dilihat pada Gambar 1.

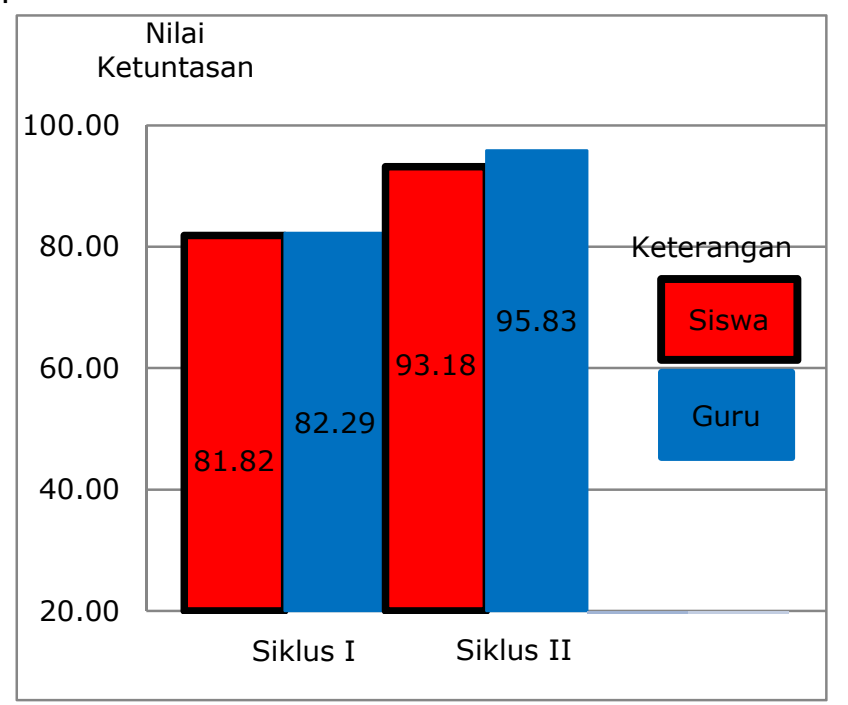

Gambar 1 Grafik Analisis Aktivitas Guru dan Siswa pada Siklus I dan Siklus II

Dari hasil penilaian afektif siswa, penilaian kinerja siswa dan penilaian keterampilan sosial siswa, diketahui terdapat beberapa kelemahan yakni: (a) Keaktifan Siswa Dalam Pembelajaran misalnya kurang memberi pertanyaan dan kurang mengeluarkan pendapatnya; (b) Sebagian siswa belum sepenuhnya menguasai praktikum yang diberikan sehingga kurang 
mampu dalam mengambil dan mengolah data dan siswa kurang bekerjasama bersama tim kelompoknya terutama kurang meyakinkan teman kelompoknya terhadap gagasan/konsep awal yang difahaminya.

Pembelajaran pada siklus II dilaksanakan untuk memperbaiki pembelajaran pada siklus I. Pelaksanaan pembelajaran pada siklus II berjalan lancer sesuai dengan rencana. Sehingga siswa terlihat lebih aktif melakukan kegiatan pembelajaran. Pada siklus II, guru berusaha meminimalisir beberapa penyebab yang mengakibatkan hasil belajar siswa pada siklus I walaupun sebenarnya telah memenuhi standar indikator keberhasilan kuantitatif dan kualitatif. Adapun yang harus dilakukan pada siklus II adalah guru lebih memperhatikan kemampuan siswa dalam menerima materi dan apabila siswa belum memahami materi maka guru mengulang menjelaskannya; Ketika proses kegiatan belajar mengajar, guru akan memperbaiki konsep awal siswa menjadi konsep yang sebenarnya (konsep ilmiah) dengan cara perubahan konseptual; guru menekankan pada siswa untuk lebih tenang pada saat diskusi dan memperhatikan apa yang disampaikan; guru harus menyampaikan untuk belajar dengan sungguh-sungguh dirumah mengenai materi yang akan di ajarkan nanti sehingga pada saat proses belajar-mengajar siswa sudah tidak salah konsep (miskonsepsi) dalam menjawab pertanyaan/permasalahan yang diberikan; guru harus lebih berusaha bersikap adil untuk memberikan perhatian yang sama tanpa membedakan siswa yang berkemampuan tinggi dan rendah.

Berdasarkan analisis tes hasil belajar siklus II, telah diketahui bahwa hasil belajar siswa sudah memenuhi indikator keberhasilan kuantitatif dengan ketuntasan belajar klasikal (KBK) siswa mencapai $92.31 \%$ dan daya serap klasikal (DSK) siswa mencapai $80.26 \%$ dimana hanya ada 2 siswa yang tidak tuntas dari 19 siswa. Dari hasil analisis kualitatif diketahui bahwa peran siswa yang sesuai dengan skenario pembelajaran dalam kegiatan pembelajaran telah terarah dengan baik. Hal ini dapat dilihat dari hasil analisis lembar observasi aktivitas guru dan siswa yang mengalami peningkatan yaitu berada pada kategori sangat baik. Sedangkan penilaian afektif siswa, penilaian kinerja siswa dan keterampilan sosial siswa juga mengalami peningkatan yaitu berada pada kategori baik dan sangat baik.

Hasil yang diperoleh pada siklus II dapat meningkat dan lebih baik dari siklus I karena faktor-faktor penyebab kekurangan pada siklus I dapat direkomendasi oleh guru. Peningkatan hasil belajar siswa dari siklus I ke siklus II dapat dilihat pada Gambar 2.

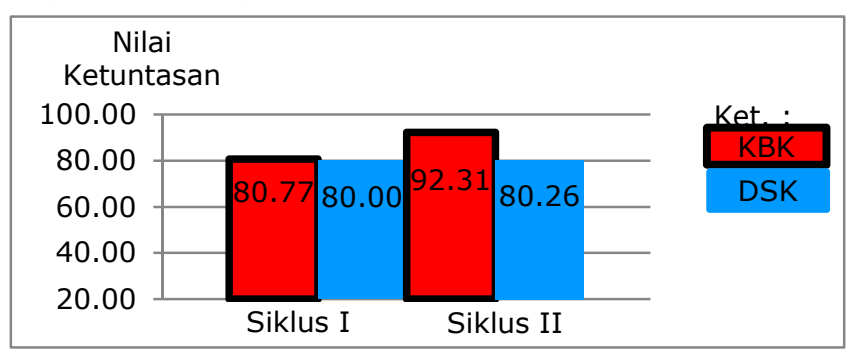

Gambar 2 Grafik Analisis KBK dan DSK Siswa Pada Siklus I dan Siklus II

Deraasarkan vampar s.L aıkecanuı Dahwa peningkatan ketuntasan belajar klasikal (KBK) dan daya serap klasikal (DSK) dari siklus I ke siklus II sebesar $14.28 \%$ dan $0.32 \%$.

Hasil analisis ketuntasan belajar klasikal dan daya serap klasikal yang diperoleh siswa pada siklus I ke siklus II mengalami peningkatan. Hal ini disebabkan karena setiap pertemuan, peneliti menyajikan materi sesuai dengan peta konsep yang telah disusun sehingga siswa tidak merasa bosan memperhatikan materi yang diberikan, melakukan aktifitas tanya jawab kepada siswa bila siswa kurang faham atau tidak mengerti, siswa bertanya dan guru menjawab, begitupun guru akan memberi pertanyaan/permasalahan dan siswa yang menjawab pertanyaan/permasalahan tersebut. Siswa diberi kebebasan untuk berbeda pendapat dalam kelompok yang kemudian akan menjadi hipotesis sebelum melakukan percobaan, siswa dapat menemukan sendiri konsep sebenarnya (konsep ilmiah) melalui kegiatan eksperimen sesuai prosedur pada Lembar Kerja kelompok (LKK), kemudian peneliti juga selalu mengontrol proses belajar siswa, dan melakukan kerja sama, membimbing pada saat kegiatan praktikum, mendiskusikan penyelesaian masalah, memancing minat siswa sehingga siswa lebih termotivasi untuk mengikuti pelajaran. Berdasarkan uraian di atas, dapat dikatakan bahwa penerapan tekhnik konflik kognitif dalam pembelajaran conceptual change berbantuan peta konsep dapat meningkatkan hasil belajar fisika pada siswa kelas XA SMA Al-Khairaat Kalukubula.

\section{KESIMPULAN DAN SARAN}

Berdasarkan hasil analisa data dan pembahasan pada penelitian ini maka dapat disimpulkan bahwa penerapan tekhnik konflik 


\section{Jurnal Pendidikan Fisika Tadulako (JPFT) \\ Vol. 1 No. 3}

kognitif dalam pembelajaran conceptual change berbantuan peta konsep dapat meningkatkan hasil belajar fisika pada siswa kelas XA SMA AlKhairaat kalukubula ini ditunjukkan oleh peningkatan hasil belajar siswa dari siklus I ke siklus II. Hasil observasi aktivitas guru dan siswa pada siklus I masing-masing berada pada kategori baik sedangkan pada siklus II berada berada pada kategori masing-masing sangat baik. Ketuntasan klasikal pada siklus I sebesar $80.77 \%$ dan pada siklus II sebesar $92.31 \%$, dan meningkat sebesar $11.54 \%$ sedangkan untuk daya serap klasikal pada siklus I sebesar $80.00 \%$ dan pada siklus II sebesar $80.26 \%$ dan meningkat sebesar $0.26 \%$.

Disarankan kepada guru maupun calon guru yang ingin menerapkan tekhnik konflik kognitif dalam pembelajaran conceptual change berbantuan peta konsep, berdasarkan penelitian di sarankan:

1) Harus lebih memperhatikan $\begin{array}{r}\text { dan } \\ \text { mengefektifkan } \\ \text { waktu }\end{array}$ selama pembelajaran.

2) Menciptakan suasana keakraban antara guru dengan siswa, tidak membuat jarak antara keduanya, menumbuhkan rasa percaya diri siswa, memberikan perhatian dan motivasi untuk senantiasa menjaga kerja sama dalam kelompok

3) Dapat diterapkan pada mata pelajaran lain karena sangat efektif untuk meningkatkan belajar mandiri, dan hasil belajar siswa.

\section{DAFTAR PUSTAKA}

[1] Lisdawati. (2010). Meningkatkan Hasil Belajar Fisika Pada Siswa kelas VIII SMP Negeri 2 Marawola melalui Pendekatan Konflik Kognitif dengan menggunakan Peta Konsep. FKIP Universitas Tadulako Palu: tidak diterbitkan.

[2] Budiningsih, C. A. (2005). Belajar dan pembelajaran. Jakarta: Rineka Cipta.

[3] Saptono, S. (2003). Pengembangan Model Conceptual Change Pada Pembelajaran IPA. Buletin Fasilitator edisi 3, hal 56-58. Jakarta: SEQIP Depdiknas.

[4] Rusmansyah. (2006). Meningkatkan Pemahaman Siswa Terhadap Konsep Kimia Karbon Melalui Strategi Peta Konsep (Concept Mapping). [Online]. Tersedia:http://www.depdiknas.go.id Jurnal/42 rusmansyah.html [27 November 2012].

[5] Dahlia. (2008). Peningkatan hasil belajar fisika dengan menggunakan teknik konflik kognitif pada siswa Kelas VIII F SMP Negeri 3 Palu. FKIP Universitas Tadulako Palu: tidak diterbitkan.
ISSN 23383240

[6] Depdiknas. (2004). Penelitian Tindakan Kelas. Jakarta: Direktorat Pendidikan Nasional. 